\title{
Editorial
}

\section{SPITZENKANDidaten and the European Union's System of GOVERNMENT}

As was the case with the previous European Parliament elections, the aftermath of the elections of 23-26 May 2019 raises constitutional issues. ${ }^{1}$ Here, we discuss the fate of the Spitzenkandidaten procedure and the implications it may have for the constitutional development of the system of government of the Union. The Union's system of government is not only determined by the letter of the law, but also by political practice. Very much like the historical development in most of the member states during the $19^{\text {th }}$ and early $20^{\text {th }}$ centuries, this practice seemed to go towards a more parliamentary system of government, from the early assertion of traditionally parliamentary powers, such as certain powers of the purse and investigative powers, to the successful application of the Spitzenkandidaten procedure in 2014. In 2019 the procedure misfired. Although that may not necessarily be the end of it, we argue that for the time being the prospects of further parliamentarisation of the Union's system of government do not look favourable, due to the systemic dominance of the European Council.

\section{Regimen mixtum and semi-parliamentarism or semi-presidentialism}

The political system of the European Union lends itself to various characterisations. It may be qualified as a regimen mixtum, the conceptual framework of pre-modern government in Europe going back to the Old Philosophers and Polybius: the division and mixture of the classic powers of monarchic, aristocratic and democratic government. ${ }^{2}$

${ }^{1}$ See WTE, TB, JHR, 'Editorial: Between the Constitutional Document and the Constitutional Settlement', 10 EuConst (2014) p. 375.

${ }^{2}$ For a principled rejection of division of powers and checks and balances, we have to look at the authors writing in the early modern era, a clear example being Thomas Hobbes, Leviathan or the

European Constitutional Law Review, 15: 609-618, 2019

(C) 2019 The Authors. This is an Open Access article, distributed under the terms of the Creative Commons Attribution licence (http://creativecommons.org/licenses/by/4.0/), which permits unrestricted re-use, distribution, and reproduction in any medium, provided the original work is properly cited. doi:10.1017/S1574019619000427 
Within the European Union viewed as a single body politic, these elements of a system of mixed government are easily identified. The monarchical element resides in the European Council. Although Article 10(2) TEU holds that the members of the European Council (and Council) are democratically accountable to their national parliaments or citizens, from the vantage point of the institutional make-up of the Union itself, the European Council finds democratic legitimacy only outside the EU political order narrowly conceived: its legitimacy is extraneously based in the national legal orders, just as once upon a time monarchs were extraneously legitimated by the grace of God - Who, nevertheless, from time to time allowed them to have their heads chopped off by successors, competitors or by the people. The European Council is the Union's leading force (Article 15(2) TEU).

The aristocratic element - the element of 'rule by the best, most virtuous' in Aristotle's definition - resides in the Commission, which derives its legitimacy from the confidence it enjoys from the European Parliament (Article 17(7) and (8) TEU). Its members are 'chosen on the ground of their general competence and European commitment' and exercise their tasks 'completely independently' (Article 17(3) TEU). In the exercise of their tasks there shall be no political or other dependence either on governments or on citizens. Mere excellence in promoting the general interest is its hallmark - so the TEU suggests. They are the promotors par excellence of the 'European general interest'. Interestingly, the Commission is the only institution that is explicitly said to serve that interest. Its president is elected at the proposal of the monarchic element, its members are selected by the Council in accord with the thus proposed Presidentelect (Article 17(7) TEU). And finally, the democratic element resides in the directly-elected European Parliament, which represents the citizens of the Union (Articles 10(2) and 14 TEU).

Most important is, of course, the mixture of these elements. Although the aristocratic nature of the Commission makes it liable to popular type-casting as an elitist institution, the question is whether and how far they are really removed from the people, in particular from their directly elected representatives

Matter, Forme and Power of a Common-wealth Ecclesiasticall and Civill (London 1651) ch. 29, entitled 'Of those things that Weaken, or tend to the Dissolution of a Common-wealth', where he deals with 'Mixt Government', p. 172: 'Sometimes also in the meerly Civill government, there be more than one Soule: As when the Power of levying money [... ] has depended on a generall Assembly; the Power of conduct and command [...] on one man; and the Power of making Lawes, [...] on the accidentall consent, not onely of those two, but also of a third; This endangereth the Common-wealth [...]. For although few perceived, that such government, is not government, but division of the Common-wealth into three Factions, and call it mixt Monarchy; yet the truth is that it is not one independent Common-wealth, but three independent Factions; nor one Representative Person, but three. In the Kingdome of God, there may be three Persons independent, without breach of unity in God that Reigneth; but where men Reigne, that be subject to diversity of opinions, it cannot be so.' 
in the Parliament. Looking at the legal and political relations between these institutions, it is clear that they are not so removed.

This brings us to a second qualification of the European Union's system of government. Over time, the pre-modern monarchs have been pushed to the margins of the political system, or ousted and replaced, and parliamentary (first in the UK, later on the European continent) and presidential systems of government (US) have seen the light. In the European Union's system of government, elements of both systems can be found: it may be considered as being semiparliamentary or - more aptly we think - semi-presidential, much like in France. On the one hand, there is the European Council, which is not responsible to the European Parliament and is the leading executive force of the Union (Article 15(2) TEU), just like the French President, who is not responsible to the French parliament, is France's leading executive force. On the other hand, there is the Commission. It needs to be invested in by and is responsible to the European Parliament, can be sent home by it with a no-confidence vote (Article 17(7) and (8) TFEU), and is the chargehand of European Council - just like the French government, which is responsible to and can be sent home by the Assemblée nationale, the directly-elected house of the French parliament, is the chargehand of the French president.

\section{Spitzenkandidaten and parliamentarisation}

In parliamentary systems, parliamentary elections not only determine the composition of parliament, but also of the government. In for instance Austria, Bulgaria, Finland, Germany, Italy, Spain, the Netherlands and the United Kingdom, and probably in most member states, parliamentary elections also decide who becomes prime minister - though not always in an equally straightforward manner, of course. Often this will be the political leader of the party that wins the most seats and that is able, on its own or by entering into a coalition with smaller parties, to command a majority in parliament or, in bicameral parliaments, in the House that is able to vote the government down. ${ }^{3}$ In short, voters in parliamentary elections in parliamentary systems decide on the composition of parliament and executive, and decide on the exercise of legislative and executive powers during the next parliamentary term. That makes parliamentary elections the central and decisive democratic and political events in those states.

In semi-parliamentary or semi-presidential systems like France, this is different. There, the election of the president of the republic is, generally, the most important democratic and political event of the nation. It is also different in the European Union. Of course, European Parliament elections are the Union's single general

${ }^{3}$ In Italy, both houses have that power. 
democratic and political event. But national parliamentary and presidential elections are collectively, and in certain instances like Germany and France even individually, of equal and arguably even greater importance, because they determine the composition of the European Council.

Now the Spitzenkandidaten procedure is grafted onto the pattern in parliamentary systems, at least arguably. ${ }^{4}$ It not only aims at giving the Parliament a decisive say in the nomination of the President of the Commission, but intends more generally to parliamentarise and democratise - in short: to politicise - the Union's system of government. This is well expressed in a resolution the European Parliament adopted on 2 February 2019 committing itself to the Spitzenkandidaten system, the González Pons Resolution:

1. Recalls that the President of the Commission will be elected by the European Parliament on a proposal by the European Council, taking into account the outcome of the European elections and after appropriate consultations have been held, and that therefore, as was the case in 2014, European political parties shall come up with lead candidates ('Spitzenkandidaten'), in order to give the European citizens the choice whom to elect as President of the Commission in the European elections;

2. Recalls that the 'Spitzenkandidaten' process reflects the interinstitutional balance between the Parliament and the European Council as provided for in the Treaties; furthermore emphasises that this further step in strengthening the Union's parliamentary dimension is a principle that cannot be overturned;

3. Stresses that, by not adhering to the 'Spitzenkandidaten' process, the European Council would also risk submitting for Parliament's approval a candidate for President of the Commission who will not have a sufficient parliamentary majority;

4. Warns that the European Parliament will be ready to reject any candidate in the investiture procedure of the President of the Commission who was not appointed as a 'Spitzenkandidat' in the run-up to the European elections; [...]

5. Underlines that the 'Spitzenkandidaten' process fosters the political awareness of European citizens in the run-up to the European elections and reinforces the political legitimacy of both Parliament and the Commission by connecting their respective elections more directly to the choice of the voters; acknowledges therefore the important added value of the 'Spitzenkandidat' principle in the goal of a strengthening of the political nature of the Commission $[\ldots] .^{5}$

The indebtedness of the Spitzenkandidaten system to parliamentary systems is even better expressed in a statement of the Christian Democratic group in the

${ }^{4}$ See also É. Pataut, 'Éditorial: Spitzenkandidaten', RTDEur (2019) p. 585 at p. 586.

${ }^{5}$ EP Resolution González Pons (7 February 2019) Revision of the Framework Agreement on relations between the European Parliament and the European Commission, P8_TA(2018)0030, A8-0006/2018. 
European Parliament, the EPP, on its website on 24 June 2019: 'A basic principle of democracy is for parties to put forward their programmes and candidates so voters can decide which policies and which leaders they want to put in place. This applies to every level: local, regional, national and European'. ${ }^{6}$

This was also how the procedure was sold in the media in the 2019 election campaign, at least in some member states, like the Netherlands: the elections were supposedly not only about the composition of the European Parliament, but also about the composition and exercise of executive power, in short about who was 'to run Brussels'; and there were several debates between the Spitzenkandidaten during the campaign across Europe.

The trend towards a more parliamentary system of government beyond the Treaty provisions, which in terms of a regimen mixtum slants the Union's system of government in favour of the democratic element, was heralded by the development since the inauguration of the first Barroso Commission - that each single member of the Commission needs the support of the European Parliament. The rule, which builds on the provision in Article 17(7) TEU according to which the European Parliament must consent to the Commission 'as a body' before it can be appointed, is a convention of the constitution developed in practice. It is now a well-established cornerstone of the relations between Commission and Parliament at the beginning of a Commissioner's tenure. ${ }^{7}$ Given the strong and continuous practice since 2005, the probability of an opinio iuris among all parties involved which expresses adherence to this practice as the only proper way of proceeding, and the likelihood that non-adherence would lead to a constitutional crisis, it can be argued the requirement of parliamentary approval of individual members is an unwritten constitutional rule, closely related to Articles 17(7), third indent, and 17(8) TEU: ${ }^{8}$ action contrary to this rule would be regarded as unconstitutional. ${ }^{\text {? }}$

${ }^{6}$ EPP Press release, 'Poll: Citizens want the Council to respect the Spitzenkandidat process' (24 June 2019) (www.epp.eu/press-releases/poll-citizens-want-the-council-to-respect-the-spitzenkandidatprocess/ $/$, visited 17 November 2019.

${ }^{7}$ For a full analysis of the events at the origin of the constitutional convention shortly after they occurred, see The Barroso Drama, special section 1, EuConst (2005) p. 217 ff., especially T. Beukers, 'The Invisible Elephant: Member States' Collective Involvement in the Appointment of the Barroso Commission', ibid., at p. 217.

${ }^{8}$ The expression 'convention of the constitution' is a category that in the British context has a very particular meaning that is not part of the common constitutional traditions of continental European countries; in the British understanding, 'law' is 'what the courts say it is' and because the courts are supposed not to be able to apply 'conventions', it is not law. This concept of 'law' is not shared elsewhere in Europe, although this does not necessarily mean that courts are competent to apply all legal rules, including this constitutional convention.

${ }^{9}$ The answer to the question if and what a court could do to establish this, and what remedy to provide, is not here considered decisive for establishing the legal nature of this practice. 
The Spitzenkandidaten operation is in line with that development. It builds on the rule in Article 17(7) TEU that the European Parliament elects the Commission president on the basis of a proposal of the European Council. The system is that the major political groups and parties nominate lead candidates for the Commission President prior to the Parliamentary elections. The agreed understanding is that the lead candidate of the group obtaining the most seats would then assume the Commission Presidency. This system was successful in 2014, in as much as the European Council approved lead candidate Juncker, who had been nominated the Christian Democrats. Only the UK, the mother of parliamentary systems in Europe, represented by David Cameron, refused to agree, but was outvoted - a qualified majority sufficed.

In 2019, however, members of the European Council had been warning that they would not allow a repetition of this success of parliamentarism. Looking at the system of government he is working in and the style he adopted as incumbent of the Elysée, it is perhaps not surprising that President Macron took the lead in the killing off the Spitzenkandidaten idea. He was followed by, amongst others, his fellow liberal leader Mark Rutte from the Netherlands - a country that adopted a parliamentary system based largely on constitutional conventions and unwritten constitutional law, and had known some quasi-monarchist set-backs in the 1870s, soon after a rule of confidence had been adopted in the 1860s. Angela Merkel, from the country where the Spitzenkandidaten system was invented, with parties prior to elections indicating who their chancellor would be in case of electoral victory, reluctantly gave up the German Spitzenkandidat, Manfred Weber, in return for one of her political protégées, Ursula von der Leyen, being appointed President instead. Hungary's Viktor Orbán triumphantly commented: 'This commission must return to its role as laid down in the founding treaty of the European Union: to act as the guardian of the treaties [...]. And it must abandon its political activism. It's not a political body'. ${ }^{10}$

It should be noted that political relations within the newly-elected European Parliament were important in breaking up the Spitzenkandidaten system this time. The socialists (PES) and Christian-democrats (EPP), who together had been a majority in the previous parliaments, now needed the liberals, who from ALDE were re-christened into RENEW Europe at the insistence of Macron. ${ }^{11}$

${ }^{10}$ E. Zalan, 'Von der Leyen aims to "rebalance Europe”, EUobserver (31 July 2019) (euobserver. com/political/145565〉, visited 17 November 2019.

${ }^{11}$ M. de la Baume, 'Macron-Liberal alliance to be named Renew Europe', Politico (12 June 2019) 〈www.politico.eu/article/emmanuel-macron-liberal-alliance-to-be-named-renew-europe/〉, visited 17 November 2019. The liberal group grew from 67 to 108. Macron's party brought 21 seats, but also the Romanian parties Uniunea Savati România and PLUS brought 8 new seats, while the British Liberal Democrats grew from one to no less than 16 seats (plus a member from the Northern Irish Alliance Party) for the group. Brexit will of course mean the group losing the latter seats again. 
The liberals, prior to Macron's movement joining, had committed to the Spitzenkandidaten system, and had supported the González Pons Resolution and other resolutions amounting to the same. But things changed after the elections - the competitors of the liberals viewed Macron, probably rightly, as the puppeteer pulling the strings of change in the background of the liberal group. This was combined with opposition to the Spitzenkandidaten system voiced by more members of the European Council than were willing to support it explicitly. ${ }^{12}$ Unlike the political situation after the 2014 elections, the political condition of a threat of voting down a candidate proposed by the European Council who had not been a Spitzenkandidat in the elections or the threat of the rejection of the full Commission, had basically disappeared. In the political circumstances after the 2019 elections, the Parliament turned out not to be 'ready to reject any candidate in the investiture procedure of the President of the Commission who was not appointed as a Spitzenkandidat in the run-up to the European elections', as it had thought it would be prior to the elections. ${ }^{13}$

\section{Whither the Union's system of government: further parliamentarisation?}

The question arises how to understand this rejection of the Spitzenkandidaten by the European Council. Is the system dead for ever? Or can it be revived? A further comparison with the political operation of the French system of government may be helpful.

The president's chief executive position in the French political system is not based on his constitutional competences, but on two facts: his direct election and the election of a majority in the Assemblée nationale that supports him it is his majority, not that of the government. However, it has happened that different political majorities resulted from the elections of president and Assemblée nationale. In that case, the president cannot ignore the will of the political majority in the Assemblée nationale and is forced to appoint a prime minister and ministers that are not to his political liking. This situation of cohabitation has occurred three times. In those periods, executive power was effectively, though not evenly, divided between the president and the government. Ordinarily the president, not the government, 'determines and conducts the politics of the nation', although the government is the institution to which Article 20 of

\footnotetext{
${ }^{12}$ Politico already early in 2018 counted 8 members of the European Council voicing opposition to the system (France, Czech Republic, Hungary, Lithuania, the Netherlands, Poland, Portugal and Slovakia), with only three outspoken supporters (Ireland, Italy and Spain), see D.M. Hertzenshorn and M. de la Baume 'Commission's Spitzenkandidat process at risk', Politico (1 February 2018, updated 9 October 2018) (www.politico.eu/article/spitzenkandidat-jean-claude-juncker-racewith-no-rules-eu-leaders-brace-for-clash-over-2019-elections/ $\rangle$, visited 17 November 2019.

${ }^{13}$ González Pons Resolution, paras. 3 and 4 quoted above.
} 
the French Constitution assigns this competence. In times of cohabitation the government, on the basis of its majority in the Assemblée, could reclaim its constitutional prerogatives. Only in the field of foreign affairs and defence, the so-called presidential domaine reservé, could the president remain dominant. To avoid such division of powers within the executive for the future, in 2000 the duration of the presidential mandate was aligned to that of the Assemblée nationale of five years and the order of the elections was reversed, i.e. presidential elections now take place before those for the Assembleee, in the hope that the French electorate will give the president that they have elected the majority in the Assemblee nationale which he or she needs in order to implement his or her political programme. So far, that has worked.

Two lessons may be drawn from the above. The first is that the exercise of political power is not always determined by the text of the constitution, but ultimately by political practice: despite Article 20 of the French Constitution, it is the French president who defines French policy. The second lesson is that under specific circumstances the lack of constitutional competences may thwart the exercise of political power by the French president.

What is the relevance of these lessons for the European Union? Let us start with the second one. Although the European Council's chief executive role is enshrined in law, it is in a way in a similar position to the French president: it lacks the administrative and legislative competences itself to execute or officially to set in motion the general directions and priorities it has defined. For the actual execution, apart from the Council - which for obvious reasons will generally follow the European Council - it is dependent on the Commission, on the European Parliament, and in other instances on the member states. Even if there existed a legal or constitutional duty for the Commission to follow up on European Council decisions - which would conflict with the complete independence that is demanded by Article 17(3) TEU - that duty could not be enforced. It is ultimately the political authority that the European Council enjoys that ensures its decisions are followed. That the president of the Commission is a member of the European Council and able to veto decisions that have to be taken by consensus (as may be a contrario deduced from Article 15(4) TEU and Article 235(2), second sentence) of course also helps. However, the European Council's authority may not be everlasting.

That brings us to the first lesson. Is it imaginable that European Parliament elections could become the central and decisive democratic and political event of the Union, which decides on the exercise of both legislative and executive powers in the following five years, as is the case in fully parliamentary systems in the member states? Or will the leading role attributed to the European Council remain so powerful as to even prevent the European Parliament deciding on the president of the Commission? 
To begin with the latter, this summer the Spitzenkandidaten system certainly received a heavy blow, but not necessarily a fatal one. Surely, it may be revived in the build-up to future elections and be successful again, if at a future moment in time a majority in Parliament is able to form a united front against the European Council by steadfastly supporting the Spitzenkandidat of the largest group, or alternatively by backing the candidate of a smaller group on the basis of some sort of a coalition agreement. But is it conceivable that the Commission, with the Parliament as its powerbase, would become the chief executive force of the Union, despite the text of the Treaty on European Union suggesting that the leading role is for the European Council (Article 15(2) TEU), similar to the French president becoming the chief executive force in France despite the letter of the French Constitution - or similar to the ministers becoming the chief executive force in European parliamentary monarchies in the course of the $19^{\text {th }}$ century?

The text of Article 15(1) TEU cannot really prevent such a development. Moreover, it is not very hard to imagine circumstances in which the Commission at least incidentally takes the lead by providing 'the necessary impetus for [the Union's] development'. Let us suppose that the European Council, due to internal tensions and the requirement of consensus for most decision-making, is struck by inertia and unable to take certain decisions. The Commission could step in under such circumstances, for instance by introducing a legislative proposal in order to have it adopted by the Parliament and a coalition of the willing in the Council (which, in contrast to the European Council, can often adopt decisions with a qualified majority). In fact, such things have happened in everyday politics, and, although exceptional, an example was the adoption of Council Decision (EU) 2015/1601 establishing provisional measures in the area of international protection for the benefit of Italy and Greece during the immigration crisis of $2015 .^{14}$

For the time being, however, the situation in which the Commission structurally becomes the chief executive of the Union would seem to be not only politically impracticable, but as things now stand also doubtful as a matter of principle. There are several reasons for this. The most important is that the European Council's democratic credentials compared to those of the European Parliament are too strong to enable the full parliamentarisation of the Union's system of government. Although it is directly elected, the democratic legitimacy of the European Parliament is empirically weakened by its relatively low electoral turnout compared to national elections which provide governmental legitimacy in most member states, even if increased electoral fragmentation and concomitant governmental instability and weakness is the common trend in member states. Also, the way the European Parliament is organised and functions, with relatively

${ }^{14} \mathrm{JHR}, \mathrm{TB}$, 'Editorial: Not dead yet. Revisiting the 'Luxembourg Veto' and its Foundations', 13 EuConst (2017) p. 1. 
loose groups that assemble representatives of national parties which formally have the same denomination but in reality are often as different as night and day, prevent the Parliament from becoming a viable political powerbase for the Commission as chief executive of the Union. ${ }^{15}$

This suggests that the present stage of European integration in democratic terms reflects a predominant legitimacy of member state polities in the governmental system. ${ }^{16}$ That seems to be the prevailing view, not only of scholarship, which nowadays largely accepts that the European Council is the Union's most important political institution, but also of the general public - which may explain why the course of events of June 2019 was so surprisingly easily accepted in the media.

To depict the European Parliament elections as just as decisive for the political course of the Union as parliamentary elections in a parliamentary system may be the easiest way to attract the interest of the electorate and persuade it to vote. But with the present state of affairs, as witnessed by political practice, it may also be a misrepresentation. We have to accept that membership of the chief executive force of the Union, the European Council, is determined by the grace and mercy of the members' national constitutional constituencies, which sanction them so as to determine the beginning and end of their European Council membership - even if the ending of it may be premised on what a national leader did or failed to do in the European Council. This implies that as far as the leading force in the EU political system is concerned, the political balance is ultimately determined by the member states. A full parliamentarisation of the Union and an ensuing majoritarian politics, as foreseen by the previous European Parliament's view on the Spitzenkandidaten system - witness the European Parliament resolutions we have mentioned - might rock the fragile political order of a Union which, like it or not, ultimately depends on the continued willingness to cooperate of the member states.

Does that mean that European Parliament elections are unimportant? Of course not. The European Parliament is the only institution within the composite European constitutional order that is able to effectively act as a counterbalance against the combined wills of the national executives in the Councils of the EU. And the importance of that function cannot be overestimated. ${ }^{17}$

JHR/LB

${ }^{15}$ See also Pataut, supra n. 4.

${ }^{16}$ For a normative justification of this state of affairs see for instance R. Bellamy, A Republican Europe of States: Cosmopolitanism, Intergovernmentalism and Democracy in the EU (Cambridge University Press 2019) in particular ch. 4.

${ }^{17}$ See for the importance of the European Parliament's countervailing power in the field of the Union's external relations C. Eckes, EU Powers Under External Pressure (Oxford University Press 2019) ch. 5. 